\title{
2 段多重重複繰返応力に対する応力修正係数の意義について*
}

\author{
河本実** 中川隆 夫***
}

\section{On the Significance of the Stress Correction Factors for the \\ Fatigue Stressing with Periodical Two Stress Amplitudes}

by

\author{
Minoru Kawamoto \\ (Faculty of Engineering, Kyoto University, Kyoto) \\ and Takao NakagawA \\ (Faculty of Engineering, Kobe University, Kobe)
}

Previously, the authors studied the fatigue lives under the reversed stress with periodical two stress amplitudes. The equation predicting fatigue lives was modified by introducing the stress correction factors. Three kinds of carbon steel were tested under such load conditions and the values of stress correction factors were obtained. At that time, however, no physical or mathematical meaning was given for these factors.

In this paper, the authors have investigated the significance of this stress correction factors by the analysis starting from the modified linear damage criterion. The conclusions obtained are as follows :

(1) The fatigue damage should be considered as the function of the practical strain amplitude (instead of the nominal strain amplitude). In this study, we introduced the damage function as

$$
D=C \sum_{j=1}^{p}\left(\varepsilon_{j}^{\frac{1}{m}} n_{j}\right) \text {. }
$$

(2) This strain $\varepsilon_{j}$ should not be the strain of the virgin material but the practical strain after various stress histories.

(3) The stress correction factors should be defined as the ratio of the $1 / \mathrm{m}$-th power average of this practical strain to the nominal strain. Accordingly, these factors are not only experimental constants but the factors with sufficient physical significance.

(Received June 26, 1964)

\section{1 緒言}

機械や構造物の使用中に受ける繰返変動応力または 重複繰返応力による材料の疲労に関しては既に多くの 研究結果か溌表されており，それらはいずれも Palmgren-Miner の直線被害則に基づいて，乙れとの比較 ならびにそれの修正を行なったものである、筆者らも 以前に 2 段多重重複繰返応力の下における炭素鋼の 疲学寿命について詳細な実験的研究を行ない，直線被 害則に基づく疲労寿命の推定式に応力修正係数を導入 し，3 種類の炭素鋼について実際にそのような応力状 態の疲労試験を行なって応力修正係数の実測值を得た。 その研究において, 筆者らは Fig. 1 亿示すようない

* 原稿受理 炤和 79 年 6 月26日

** 正 会 員 京都大学工学部 京都市左京区吉田本町

*** 正 会 員 神严大学工学部 神市市灘区六甲台町 1

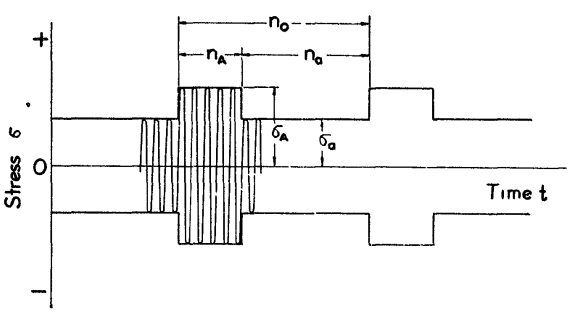

Fig. 1. Many-fold multiple reversed stress in two levels.

わゆる 2 段多重重複繰返応力の下における疲労寿命を 計算するに当って直線被害則

$$
\sum_{J} \frac{n_{j}}{N_{j}}=\frac{n_{1}}{N_{1}}+\frac{n_{2}}{N_{2}}+\cdots \cdots \cdots \cdots \cdot=1
$$

から出発し次のような疲労寿命の修正計算式を得た。 
すなわち，Fig.1 の応力状態の下における破壊までの 繰返数は

$$
N_{t}=\frac{n_{0}}{\frac{n_{a}}{N_{a}^{\prime}}+\frac{n_{A}}{N_{A}^{\prime}}}=\frac{1}{\frac{(1-\nu)}{N\left(i_{a} \sigma_{a}\right)}+\frac{\nu}{N\left(i_{A} \sigma_{A}\right)}}
$$

で表わされる.とてでn日 繰返数, $n_{a}$ は $n_{0}$ のうち低いほうの応力 $\sigma_{a}$ の作用する繰 返数, $n_{A}$ は同様涪いほうの応力 $\sigma_{A}$ の繰返数, $\nu=\frac{n_{A}}{n_{0}}$ である。 また $N(\sigma)$ は一定応力振幅 $\sigma$ が作用すると きの破壊繰返数（疲学寿命）である、 $i_{a}$ および $i_{A}$ は 応力振幅変更によって $\sigma_{A}$ および $\sigma_{a}$ なる両応力の相 互干渉 (Mutual interaction) のために直線被害則か らはずれるととを示す応力 $\sigma_{a}$ および $\sigma_{A}$ 亿対する修

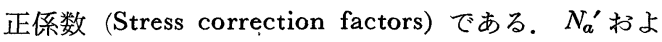
び $N_{A}{ }^{\prime}$ は $N_{a}^{\prime}=N\left(i_{a} \sigma_{a}\right)$ ，および $N_{A}{ }^{\prime}=N\left(i_{A} \sigma_{A}\right)$ を表 わす、筆者らの実験結果によればての応力修正係数は，

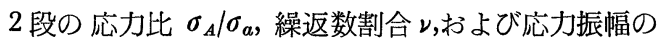
レベルによって変わるが,だいたい $i_{a}>1, i_{A}<1$ であ る. 高応力の修正係数 $i_{A}$ は耐久限度上昇を表わし, 低応 力の修正係数 $i_{a}$ は疲学寿命の低下を表わす。実験を 行なった当時，筆者らはてれらの応力修正係数に対し， 応力変更わよびその作用順序 (Sequence) に基因する 両応力の相互干渉を表わす係数であるとする以外何 らの物理的ないしは数学的意義を与えていなかった。

それは筆者らが直線被害則からの偏りがかかる疲学試 験中の材料の示す応力一ひずみ挙動と密接な関係をも つものと考光るものの，てれらに対する充分な実験的 基礎資料をもたなかったからである.最近, 熱疲労や塑 性疲労試験が盛んに行なわれるようになり, 疲労試験 中の応力とひずみが測定され，その挙動も漸次明らか となってきたので，ての研究で筆者らは疲労被害と応 カ一ひずみ挙動とを関係づけて考えてみるととにする.

また，以前に筆者らは応力振幅力湾化する場合の疲 学試験の結果を整理するのに換算応力を用いるのが便 利であることを提案し，てれに上述の応力修正係数を 適用した。沉概要を述べると次のようである。まず 直線被害則が成りたつと仮定すると， $\sigma_{j}$ なる応力を $n_{j}$ 回受けたときの疲労被害は $n_{j} / N_{j}$ で表わされ， $\sigma_{1}, \sigma_{2}$, $\sigma_{3}, \cdots \cdots$ 小る応力をそれぞれ $n_{1}, n_{2}, n_{3}, \cdots \cdots$ 回相次いで 受けたときの累積被害は

$$
D=\sum_{j}\left(\frac{n_{j}}{N_{j}}\right), \quad(j=1,2,3, \cdots)
$$

で表わされる。いま $S-N$ 曲線が

$$
\sigma=A N^{-m} \quad(m>0)
$$

で近似されるものと仮定すると，(4)式および(3)式より 被害は

$$
D=A^{-1 / m} \sum_{j}\left(\sigma_{0}^{1 / m} n_{\imath}\right)
$$

となる. こてで $A$ および $m$ は実験定数で材料によ って異なる。いまての被害が一定応力振幅 $\sigma_{r}$ t $\sum_{j} n_{j}$ 昭和 40 年 3 月
回受けたときの被害

$$
D=A^{-1 / m} \sigma_{r}^{1 / m} \sum_{j} n_{j}
$$

に等しいものとおくと $\sigma_{r}$ は

$$
\sigma_{r}=\left\{\frac{\sum_{j}\left(\sigma_{j}^{1 / m} n_{j}\right)}{\sum_{j} n_{j}}\right\}^{m}
$$

となる，乙の一定応力振幅 $\sigma_{r}$ を繰返変動応力（また は重複繰返応力）にわける換算応力 (Reduced stress) と呼ぶ.てれは応力振幅が階段状変化をせず, 連続的に 変化する場合にも，またまったく不規則に変化する場

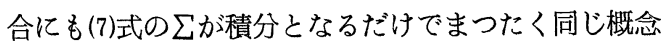
で用いるととができる．欧米特にスウェーデンでは変 動荷重を受ける航空機の疲労寿命を整理するのにての 換算応力を用いている。 $(S-N$ 曲線が, 片対数線図で直 線関係にある場合も同様の概念が適用可能である.) 2 段多重重複綝返応力 (Fig. 1) のときには換算応力は

$$
\sigma_{r}=\left\{(1-\nu) \sigma_{a}^{1 / m}+\nu \sigma_{A}^{1 / m}\right\}^{m}
$$

となる，乙のような換算応力 $\sigma_{r}$ を用いると，応力振 幅力湾化する場合の疲労試験結果を一定応力振幅の $S$ $-N$ 線図上に重ねて表示できて便利である。もし実験 結果を示す点が $S-N$ 曲線上に あるならば直線被害則 が成りたち，しからざるときはその逆であり，一目瞭 然である. 前述のように一般には直線被害則は成りた たないから，上述の応力修正係数を用いて換算応力は 次のように修正される。

$$
\sigma_{r}=\left\{(1-\nu)\left(i_{a} \sigma_{a}\right)^{1 / m}+\nu\left(i_{A} \sigma_{A}\right)^{1 / m}\right\}^{m}
$$

\section{2 応力修正係数の意義について}

こてで(7)式にもどって考光ると， $\sigma_{j}(j=1,2,3, \cdots p)$ なる呼び応力がそれぞれ $n_{j}$ 回 $(j=1,2,3, \cdots p)$ 相次 いで作用するような重複繰返応力の場合，その被害効 果は(7)式で示される一定応力振幅 $\sigma_{r}$ が $\sum_{j=1}^{p} n_{j}$ 回作用 したときの被害効果に等しいというととであった。筆 者は疲労被害は繰返応力作用下の応力一ひずみ挙動と 密接な関係があるものと考帛ており，したがって，応 力を input として与える場合, 疲学被害は response であるひずみの何らかの関数の形で表わさるべきであ ると考える、そてで，まず Hooke の法則に従う弾性 式 $\sigma=E \varepsilon(7)$ 式に代入すると

$$
\varepsilon_{r}=\left\{\frac{\sum_{j=1}^{p}\left(\varepsilon_{j}^{1 / m} n_{j}\right)}{\sum_{j=1}^{p} n_{j}}\right\}^{1 / m}
$$

なる換算ひずみが得られ，乙のときの疲労被害は (5) 式に $\sigma=E \varepsilon$ を代入して

$$
D=\left(\frac{E}{A}\right)^{1 / m} \sum_{j=1}^{p}\left(\varepsilon_{j}^{1 / m} n_{\jmath}\right)=C \sum_{j=1}^{p}\left(\varepsilon_{j}^{1 / m} n_{j}\right)
$$

となる。とこで $G=(\boldsymbol{E} / A)^{1 / m}$ である。すなわち，直 線被害則に従うならば, 重複繰返応力を受けた材料の 
疲労被害は(11)式で示されるように $\varepsilon^{1 / m}$ の形で表わさ れる. この場合, $\varepsilon$ は呼び応力 $\sigma$ を Hooke の法則 によってひずみに書き直したいわゆる呼びひずみであ る.しかし, 害際には材料は弾性的でなく, 疲労被害 なるものも非弾性の場合に生ずるものであるから，疲 労被害を表わすには（呼びひずみでなく）非弾性的な 実際のひずみで表わさねばならない，しかも，一定応 力振幅の場合でも，生ずる非弾性ひずみはFig. 2 のよ うに繰返数とともに増す.一般に $n$ 回目のサイクルに おけるひずみ振幅は

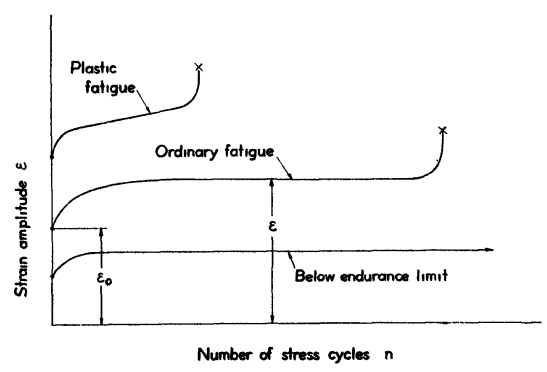

Fig. 2. Variation of strain amplitude during reversed stressing.

$$
\varepsilon=\varepsilon(n)=\frac{\sigma}{E}+k_{1} \sigma^{p}+k_{2} \sigma^{q}\left(1-e^{-\lambda n}\right)+k_{3} \sigma^{r} n^{s}
$$

なる形で近似できる，乙とで第 1 項の $\frac{\sigma}{E}=\varepsilon_{e}$ は弾性 ひずみ振幅, 第 2 項の $k_{1} \sigma^{p}=\varepsilon_{p}$ は初期塑性ひずみ振 幅でともに繰返数に関係なく， $\varepsilon_{e}+\varepsilon_{p}=\varepsilon_{0}$ (Fig. 2 参 照) は初期ひずみ振幅である，第 3 項は遷移ひずみ振 幅，第 4 項は定常ひずみ振幅を表わす．塑性疲労のよ うな高応力域では Fig. 2 亿示すようなひずみ変化を するので第 4 項が必要であるが，通常の疲労では図の ようにある繰返数の後ひずみ振幅は一定值に落ち着く. すなわち，

$$
\varepsilon=\frac{\sigma}{E}+k_{1} \sigma^{p}+k_{2} \sigma^{q}=\text { indep. of } n
$$

この一定ひずみ をを(11)式の呼びひずみの代わりに用い るとととし，(11)式はそのまま非弾性の場合にも成りた つものとする*1.

こうすれば(11)式の疲労被害 $D$ は呼びひずみ振幅 $\frac{\sigma}{E} て ゙$ はなく，実際のひずみ振幅で表わされる，とのひずみ を(11)式に入れ，乙れを 2 段多重重複繰返応力の場合に 適用する。

まず最初に $\sigma_{a}$ なる応力を $n_{a}$ 回作用せしめたとき の疲労被害は

$$
D_{a 1}=C \varepsilon_{a 1}^{1 / m} n_{a}=C n_{0}(1-\nu) \varepsilon_{a 1}^{1 / m}
$$

である. 次に応力振幅を $\sigma_{A}$ 亿変更し, ての応力を $n_{A}$ 回作用させるときそれによる被害は

$$
D_{A 1}=C \varepsilon_{A 1}{ }^{1 / m} n_{A}=C n_{0} \nu \varepsilon_{A 1}^{1 / m}
$$

となるものと考えられるが，乙の式中の $\varepsilon_{A 1}$ は処女 材のひずみ振幅であるから罗当でない.Fig. 3 は筆者

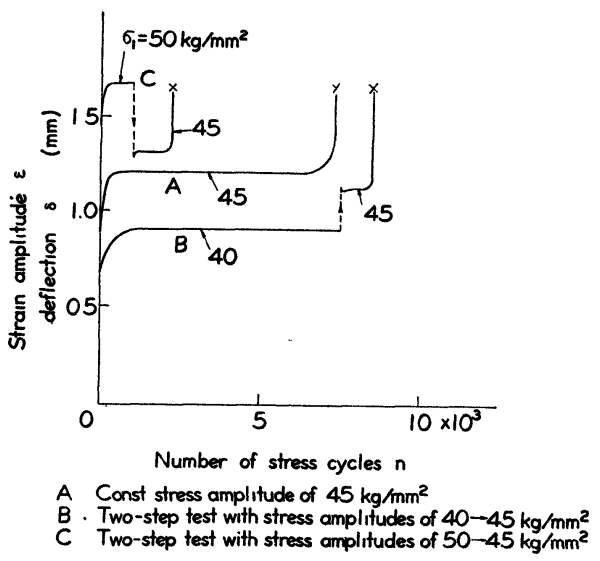

Fig. 3. Variation of strain amplitude during two-step load fatigue tests.

らか溉に行なった実験結果の一部で，2段 2 重重複回 転曲げ疲労中のひずみ振幅の変化を示したもので, 図 の曲線B は応力 $40 \mathrm{~kg} / \mathrm{mm}^{2}$ より $45 \mathrm{~kg} / \mathrm{mm}^{2}$ に step up したもので，乙のときの変更後のひずみ振幅は好女材 (曲線A）に $45 \mathrm{~kg} / \mathrm{mm}^{2}$ を作用させたときのひずみ

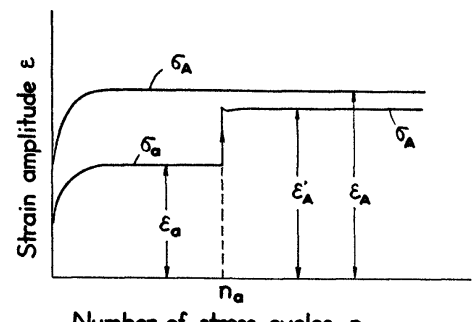

Number of stress cycles $n$

(a) Step-up test

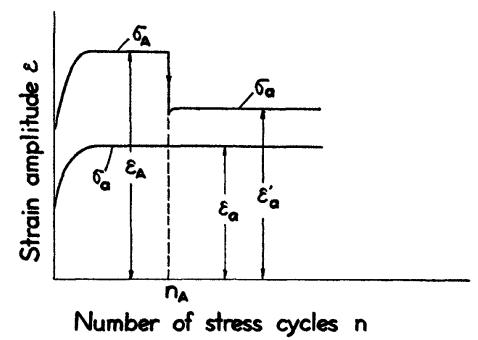

(b) Step-down test

Fig. 4. Explanatory figures representing changes of the strain levels during two-step load fatigue tests.

*1 繰返変動応力のときには $D=C \int \varepsilon^{1} / m d n$ となる，1サイクル中の ヒステリシスループの面積が $q \varepsilon$ に比例し， $\sigma$ との関係はだい たい $\sigma=C_{1} \varepsilon$ で近似されるとすると $\frac{d D}{d n}=C_{\varepsilon}^{1 / m} ; \quad D=C \int \varepsilon^{1 / m d n}$

なとり，(11)式および上記皘分形とおくととは妥当と考えられる． 
振幅より低くなっている．Fig. 4(a) はこれを説明し たもので, 今の 2 段多重の場合 $\sigma_{a}$ を $n_{a}$ 回受けた後 の $\sigma_{A}$ に対するひずみ振幅 $\varepsilon_{A}^{\prime}$ は処女材が $\sigma_{A}$ なる応 力を受けたときのひずみ振幅 $\varepsilon_{A}$ とは異なっている. それゆえ，(15)式の $\varepsilon_{A 1}$ の代わりに $\varepsilon_{A 1}^{\prime}$ でなければな らない.よって

$$
D_{A 1}=C n_{0} \nu \varepsilon_{A 1}^{\prime 1 / m}
$$

となる. 同様に次の応力振幅 $\sigma_{a}\left(n_{a}\right.$ 回) 亿対してはや はり Fig. 3 の実験的事実と Fig. 4 (b) の説明から 疲労被害は

$$
D_{a 2}=C n_{0}(1-\nu) \varepsilon_{a 2}^{\prime}{ }^{1 / m}
$$

となるべきである、したがって，第 1 回目の変動サイ クル間の累積被害は

$$
\begin{aligned}
& D_{1}=D_{a 1}+D_{A 1}=C n_{0}\left\{(1-\nu) \varepsilon_{a 1}^{1 / m}\right. \\
& \left.+\nu \varepsilon_{A 1}^{\prime 1 / m}\right\}
\end{aligned}
$$

第 2 回目の変動サイクルでは

$$
\begin{aligned}
& D_{2}=D_{a 2}+D_{A 2}=C n_{0}\left\{(1-\nu) \varepsilon_{a 2}^{\prime 1 / m}\right. \\
& \left.+\nu \varepsilon_{A 2}^{\prime}{ }^{1 / m}\right\}
\end{aligned}
$$

第 $k$ 回目では

$$
\begin{aligned}
& D_{k}=D_{a k}+D_{A k}=C n_{0}\left\{(1-\nu) \varepsilon_{a k}^{\prime 1 / m}\right. \\
& \left.+\nu \varepsilon_{A k}^{\prime}{ }^{1 / m}\right\}
\end{aligned}
$$

となる、 $z$ 周期で破壊するものとすれば

$$
\begin{aligned}
& 1=\sum_{k=1}^{z} D_{k}=C n_{0}\left\{(1-\nu) \sum_{k=1}^{z} \varepsilon_{a k}^{\prime}{ }^{1 / m}\right. \\
& \left.+\nu \sum_{k=1}^{z} \varepsilon_{A k}^{\prime}{ }^{1 / m}\right\}
\end{aligned}
$$

ことで

$$
\begin{aligned}
& \frac{1}{z} \sum_{k=1}^{z} \varepsilon_{a k}^{\prime}{ }^{1 / m}=\bar{\varepsilon}_{a}^{1 / m} \\
& \frac{1}{z} \sum_{k=1}^{z} \varepsilon_{A k}^{\prime}{ }^{1 / m}=\bar{\varepsilon}_{A}^{1 / m}
\end{aligned}
$$

なる $1 / m$ 乗平均を用いると(21)式は

$$
1=C n_{0} z\left\{(1-\nu) \bar{\varepsilon}_{a}^{1 / m}+\nu \bar{\varepsilon}_{A}^{1 / m}\right\}
$$

となる. 破壊までの繰返数 (疲労寿命) は $N_{t}=z n_{0}$ で あるからこれを(23)式に入れると

$$
N_{t}=\frac{1}{C\left\{(1-\nu) \bar{\varepsilon}_{a}^{1 / m}+\nu \bar{\varepsilon}_{A}^{1 / m}\right\}}
$$

となる. こてで前述の呼びひずみ振幅との比をとって

$$
\begin{aligned}
& \frac{\bar{\varepsilon}_{a}}{\varepsilon_{a}}=i_{a} \\
& \frac{\bar{\varepsilon}_{A}}{\varepsilon_{A}}=i_{A}
\end{aligned}
$$

とおく，てれを(24)式に代入すると

$$
\begin{aligned}
N_{t} & =\frac{1}{C\left\{(1-\nu)\left(i_{a} \varepsilon_{a}\right)^{1 / m}+\nu\left(i_{A} \varepsilon_{A}\right)^{1 / m}\right\}} \\
& =\frac{1}{C\left\{(1-\nu)\left(\frac{i_{a} \sigma_{a}}{E}\right)^{1 / m}+\nu\left(\frac{i_{A} \sigma_{A}}{E}\right)^{1 / m}\right\}} \\
& =\frac{1}{\frac{(1-\nu)}{N\left(i_{a} \sigma_{a}\right)}+\frac{\nu}{N\left(i_{A} \sigma_{A}\right)}}
\end{aligned}
$$

となって(2)式と同じ式を得る，すなわち， $i_{a}$ および $i_{A}$ は前述の応力修正係数である.

このように応力修正係数 $i_{a}$ および $i_{A}$ は実験定数 であるけれども，上述の(22)および(25)式で定義せられる ものであり，実際に材料の示す応答（ひずみ振幅）の $1 / m$ 乗平均値と呼びひずみ振幅との比を表わすもので, もし, あるスペクトルをもつ繰返変動応力を受けたと きのひずみの值が実測され，乙れらの繰返数に対する 変化の曲線が得られるならば積分によっててれらの係 数が求められるはずであり, 単なる実験定数でなく, 疲労進行中に実際に材料の示す応力一ひずみ挙動と密 接な関係をもつものであるから充分物理的意義を有す るものである.ただてれら複雑な応力経歴 (Stress history) を受ける材料のひずみ変化を求めることはか なり手数のかかることなので，応力変化が比較的単純 な場合を除いては，乙れの最終結果として得られる応 力修正係数でカバーするほかはないのである，直線被 害則に対し, 種々の修正が提案されているが, 筆者らの ように応力(またはひずみ)を修正するものは見当らな いようである。しかも応力を修正する方法を採用する ことにより，耐久限度を含む取扱いができる点で，筆 者らの方法は有利である.

\section{3 多段多重重複繰返応力への応用}

以上の諸式は 2 段多重重複繰返応力に対するもので あるが，応力振幅の種類が三つ以上，たとえば $p$ 種類 あるときにもこの同じ概念を拡張して用いることがで きる.すなわち，乙の場合には $j$ 番目の応力振幅に対 する応力修正係数を $i_{j}$, 繰返数割合を $\nu_{j}=n_{j} / n_{0}$ とする 之, (26)式に相当して, 多段多重重複繰返応力に対する 疲労寿命は次の式で与えられる。

$$
N_{t}=\frac{1}{\sum_{j=1}^{p} \frac{\nu_{j}}{N\left(i_{j} \sigma_{j}\right)}}
$$

なお，疲労被害に関する以上の概念は $S-N$ 曲線の方 程式の誘導にも，また， 2 段 2 重重複繰返応力におけ る二次応力での残存寿命の推定にも利用できるが省略 する。

\section{4 結言}

2 段多重重複繰返応力に対する疲労寿命の計算式に 導入した応力修正係数の意義について研究し, 次の結 論を得た.

（1）疲労被害 $D$ は（呼びひずみでなく）繰返応力作 用下の実際のひずみ振幅の関数と考えるべきである. この研究では $D=C \sum_{j=1}^{p}\left(\varepsilon_{j}^{1 / m} n_{j}\right)$ なる形の被害関 数を用いた。

(2) このひずみ振幅は処女材のひずみ とではなく， 過去に受けてきた応力経歴のため，処女材とは異なっ

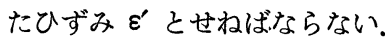


(3) 応力修正係数は乙れら実際のひずみ 振幅の $1 / m$ 乗平均值と呼びひずみ振幅との比で定義さるべきもの である、したがって単なる実験定数でなく，充分物理 的意義を有する.

この研究に関しては, 京都大学工学部機械工学教室 河本研究室の研究員諸兄に熱心なで討論を賜わり，ま た特にそれに関して大学院博士課程学生柴田俊忍君の で協力と貴重なで批判をいただいた，紙上にて厚くお 礼申し上げる次第である。

(昭和 39 年 5 月 14 日 日本材料学会第13期総会講演会にて講演)

\section{参考文 献}

1)たとえば,

材料試験，8，72 (1959); Corten, H.T., and

T.J. Dolan, Internat. Conf. Fatigue of Metals, Proc., 235 (1956) ; Freudenthal, A.M., and R. A. Heller, Internat. Conf. Fatigue of Aircraft Structures, Proc., Academic Press, 146 (1956) および J. Aero Space Sci., 26, 431 (1959).

2) Palmgren, A., VDI, Z., 68, 339 (1924) ; Miner, M.A., ASME, J. Appl. Mech., 67, A-159(1945) ;
.西原利夫，河本実，山田敏郎，機械学会論文集， 10, 38-I , 23 (1944).

3 ) 河本実, 中川隆夫，村上哲夫，材料試試， 4, 49, (1955) ; 小西一郎ほか, Engg. Res. Inst., Kyoto Univ., Tech. Rep., 8, 17 (1955); 河本実, 中川 隆夫, 北川正治, 日本材料試験協会第 4 期総会講 演会前刷，3 (1955); 河本実，中川隆夫，川並高 雄, 同上, 第 5 期, 同上, 9 (1956); 河本実, 中 川隆夫，小浜弘幸，同上，第 6 期, 同上, 24(1957) 河本実, 中川隆夫, 1st Japan Cong. Test. Mat., Proc., 6 (1958) ; 河本実, 中川隆夫, 柴田俊忍, 本田宜史，機械学会論文集，30，27，(1964).

4) 河本実, 中川隆夫, 第 6 回応用力学連合講演会前 刷, 1 (1956) ; 中川隆夫, 学位論文 (京都大学) 32 (1958); 河本実, “金属の疲労”, p. 229(1962) 朝倉書店。

5 ）中川隆夫ほか, 日本機械学会関西支部第 209 回講 演会前刷，15 (1961) ; 同上，日本機械学会 関西 支部第37期総会講演会前刷，141（1962）.

(機械学会論文集，31，226（1965）に掲載子定)。 